\title{
How Globally Contagious Was the Recent US Real Estate Market Crisis? Evidence Based on a New Contagion Test
}

\author{
Abdulnasser Hatemi-J \\ UAE University \\ E-mail: AHatemi@uaeu.ac.ae \\ Eduardo Roca \\ Department of Accounting, Finance and Economics, \\ Griffith University \\ Nathan, Queensland, Australia 4111 \\ Tel: +61-7-38757583, Fax: +61-7-3875 7760 \\ Email: E.Roca@griffith.edu.au \\ (corresponding author)
}

\begin{abstract}
This paper utilizes a new contagion test based on case-resampling bootstrap technique to investigate whether there is any contagion effect in the interaction of the US real estate market with those of Australia, Japan and the UK arising out of the recent US real estate crisis or subprime crisis. Contrary to expectations, it is found that the relationship of the US market with the other markets following the US real estate market crisis cannot be characterized as one with contagion effect. Its relationship with the other markets is rather characterized by dependency behavior that prevails regardless whether the markets are under distress or not.
\end{abstract}

Running title: Testing for US Real Estate Market Contagion Effect

JEL Classifications: F36, G15, C22

Keywords: Contagion; Case-resampling Bootstrap; Dependency; Real Estate 


\section{Introduction}

In the course of interactions between markets, co-movements or spill-over effects occur which are driven by fundamental factors such as trade linkages, capital flows and banking linkages (Glick and Rose, 1999). These co-movements may intensify as a result of changes in the fundamental factors that underpin the interaction between markets. However, these spill-over effects may increase beyond the level called for by fundamentals as a consequence of the reaction of markets to non-fundamental factors which may drive them to exhibit herding behaviour. In this situation, the co-movements are said to contain contagion effects.

It is important to determine whether the spill-over effects or co-movements between markets contain contagion effects since contagion, being the result of non-fundamental factors, indicates the existence of market inefficiency. As explained in the next section, it is claimed that during periods of distress, interactions between markets could be highly susceptible to the presence of contagion effects. With financial markets being globalised, there are now more interactions and interdependence between markets and with markets experiencing crisis situations, there is a suspicion that co-movements between markets consist of contagion effects.

In this paper, we investigate the issue of contagion in real estate markets. It is claimed that real estate markets may be highly susceptible to contagion as these markets have become globalised over the past decade (Bardhan and Kroll, 2007). In particular, we investigate the extent by which the recent US real estate crisis or sub-prime crisis led created contagion effects in the real estate markets of the UK, Japan and Australia. Examining real estate market contagion with a focus on the US market is highly important and very topical. First, the recent US real estate market crisis has precipitated the still on-going global financial and economic crisis. Second, the US real estate market is the largest and most globalised in the whole in the whole world (Bardhan and Kroll, 2007). Given the severity of the crisis and the great publicity it attracted worldwide and the worldwide reach of the US market, one would expect that the distress situation of the US market would have created significant contagion effects on other markets. There would be expectations that the crisis would have driven investors away from the real estate market in other countries for fear that what has happened in the US real estate market could also happen in these countries. 
In our investigation, we make use of a new contagion test based on case-resampling bootstrap technique developed by Hacker and Hatemi-J (2005) that performs accurately when the financial markets are under distress and the standard assumption of normal distribution and constant variance is not fulfilled. We utilize this bootstrap test to both estimate the underlying parameters and to test their statistical significance. A more detailed discussion is provided later in the paper - in Section 3, with regards to the merits and details of this test vis-à-vis existing contagion tests.

The rest of the paper is organised in the following manner. The next section provides a discussion of contagion as it relates to real estate markets. Section 3 describes the test for contagion used in this paper. Section 4 discusses the data and presents the empirical results. The summary and conclusions are provided in the last section.

\section{Contagion and Real Estate Markets}

Conceptually, contagion is defined as spill-over effects or co-movements between markets that are caused by non-fundamental factors. There are a number of different explanations as to why contagion occurs during a crisis. These explanations generally relate to information cascade as well as herd behaviour. Information about the crisis in one market may lead to a shift in expectations or sentiment with regard to the prospects in other markets. This may then lead investors in these other markets to sell off assets which precipitate a domino effect.

Theoretical models, therefore, point to the role of a third party such as investors or banks, as a channel for contagion. The actions of these agents during a crisis situation result in a significant link between markets which were previously thought to be unlinked or slightly linked. Investors and banks in the market hit by a crisis may experience liquidity problems and may therefore choose to liquidate their investments in other markets in order to raise the much-needed funds. Also, the decrease in the value of their investments in the market in crisis may lead investors to sell-off their holdings in other markets in order to re-balance their portfolios. In so-doing, investors and banks therefore transmit the crisis from one market to other markets. 
As investors and banks in the market with crisis undertake these actions of liquidating their investments in other markets, other investors in the non-crisis markets may interpret these actions as information-based and as a signal that prospects in the non-crisis markets are also negative (King and Wadwhani, 1990; Calvo and Mendoza, 2000, and Yuan, 2005; Romer, 1993 and Hong and Stein, 1999). Information therefore cascades which may then lead these other investors to follow the same actions. In this case, herding behaviour starts to occur among investors and the crisis therefore spills over to other markets (Jokipii and Lucey, 2007) ${ }^{1}$.

Real estate markets are now becoming globalised and integrated (Bardhan and Kroll, 2007). This globalisation has been mainly driven by the internationalisation of real estate investments arising from the introduction of common real estate investment vehicles Eichholtz and Kok, 2007). For example, from 2001-2006, cross-border investments tripled to US\$ 116 billion, which represents 20 percent of all property investment worldwide (Hobbs, Chin and Topintzi, 2007). Foreign capital inflows into a country can now easily find their way into the real estate market. In addition to the globalisation of investment, other factors that have significantly contributed to the globalisation of real estate markets are the internationalisation of real estate service providers, the development of more transparent international benchmarks or standards in real estate across the globe such as the recently published Real Estate Transparency Index of Jones Lang LaSalle (JLL, 2008), the reduction of political barriers, and the liberalisation of capital markets which also give rise to new financial instruments which allow foreign investors similar or almost equal footing with local real estate investors (Eicholtz, et al. 2009). These developments lead into what La Porta, et al. (2000) call functional convergence of markets.

As a consequence of this globalisation and integration, it is expected that there will be increased co-movements and contagion among real estate markets internationally. However, real estate is non-tradable and real estate markets have been found not to respond rapidly to international shocks (Bardhan et al. 2007). Hence, if contagion in real estate markets is present, it will have to arise through the other channels in terms of investor liquidity,

\footnotetext{
${ }^{1}$ There are still other channels of contagion which we do not discuss here further. Wealth constraints are one of them. Xiong (2001) studies wealth constraint as an amplification mechanism, while Kyle and Xiong (2001) study it as a spillover mechanism. Also, Gromb and Vayanos (2002) develop an equilibrium model of arbitrage trading with margin constraints to explain contagion. Contagion may be due to wealth effects.
} 
portfolio rebalancing and information channel. Hence, it is not clear to what extent would international contagion affect real estate markets.

Very few papers have investigated the issue of contagion among real estate markets globally, particularly in relation to the recent US real estate market crisis. This limited number of studies has come up with mixed results. Fry et al. (2008) investigated, among others, contagion among the real estate markets of the US, the UK, Australia, Germany, Japan and Hong Kong using a contagion test that relies on changes in higher moments. The study found no evidence of contagion among the markets. Bond et al. (2006) investigated the extent of contagion among the real estate markets of Australia, Hong Kong, Japan, Singapore and the US. Using a multivariate latent factor model, contrary to Fry, et al. (2008), the study found existence of contagion among the markets. Mun (2005) investigated the extent of contagion among real estate markets of the Pacific Rim countries during four financial crises - Mexican, Asian, Russian and Brazilian. The study also found evidence of contagion effects among the markets. Wilson and Zurbruegg (2004) examined contagion of the Thailand real estate market on the markets of Australia, Hong Kong, Malaysia and Singapore but found little evidence for market contagion arising out of the 1997 Asian crisis. Both Mun (2005) and Wilson and Zurbruegg (2004) used the Forbes and Rigobon methodology to estimate contagion.

Thus, there is scope for the current study. The focus of our paper is the contagion effect of the US real estate market on those of the UK, Japan and Australia. We apply a new contagion test developed by Hacker and Hatemi-J (2005) which is based on a pairwise bootstrap technique. This technique overcomes problems of non-normality and change in volatility that characterize financial data especially during crisis periods. We utilize this bootstrap test to both estimate the underlying parameters and to test their statistical significance. None of the existing papers on real estate market contagion has used this methodology.

\section{Contagion Test}

In terms of an operational definition of contagion, there is no general agreement within the literature. However, one that is highly used refers to contagion as "a significant increase in cross-market linkages after a shock to one country (or group of countries)” (Forbes and 
Rigobon, 2002). Based on this definition, a number of studies have been conducted that estimate the correlation coefficients between different markets (see for example, King and Wadhwani, 1990; Lee and Kim, 1993; Calvo and Reinhart, 1996; Forbes and Rigobon, 2002, Hon, Strauss and Yong, 2004; and Pretorius and Beer, 2004). Other commonly used methods for testing contagion include: (1) the use of the variance-covariance matrixes in an ARCH or GARCH context to investigate spill-overs between markets (see for example Hamao, Masulis, and Ng, 1990), (2) the examination of changes in a cointegrating vector between countries (see for example Longin and Solnik, 1995, and Granger, Huang, and Yang, 2000), and (3) the investigation of the determinants of different markets' susceptibility to financial crises (see for example Eichengreen, Rose, and Wyplosz, 1996; and Forbes, 2004). ${ }^{2}$

Although contagion tests based on the changes in correlation coefficients seem straightforward, Forbes and Rigobon (2002) pointed out that the increase in correlation between markets after the crisis could be biased if the volatilities also increased. They therefore calculated correlation coefficients that are adjusted for the changes in volatilities. Based on asymptotic t-distribution, they then tested whether the increase in adjusted correlations after the crisis are statistically significant. Their results show that, contrary to the results of many previous studies, in a number of crises, the increase in adjusted correlations were not statistically significant, and thus, contagion effects were not present.

Forbes and Rigobon (2002) therefore adjust the correlation coefficients to remove the bias created by the change in volatility between periods when there is no change in the true regression slope coefficient. ${ }^{3}$ Hatemi-J and Hacker (2005) suggest concentrating on the estimated slope coefficient in a regression of a financial variable in one market versus a financial variable in another instead of on the correlation coefficient between these variables. The authors develop a case-resampling bootstrap test for contagion that performs accurately when the financial markets are under distress and the standard assumption of normal distribution and constant variance is not fulfilled. A statistical software component that is developed by Hacker and Hatemi-J (2009) is used to do the calculations. To test for the contagion effect we make use of the following regression:

\footnotetext{
2 Forbes and Rigobon (2002) provide a review of contagion tests based on cross-correlation coefficients and other methods which are used in some of the articles mentioned here. Still another empirical approach in testing for contagion is to examine whether Granger causality changes during the crisis period, as used for example in Granger, Huang, and Yang (2000) and Hatemi-J and Roca (2005).

${ }^{3}$ Forbes and Rigobon (2002) show that their adjustment is algebraically equivalent to one suggested by Boyer, Gibson, and Loretan (1999) and Loretan and English (2000).
} 


$$
R_{i, t}=a_{1}+a_{2} D_{t}+b_{1} R_{U S, t}+b_{2} D_{t} R_{U S, t}+u_{t}
$$

The denotations are defined as the following:

$R_{i, t}$ is the continuous return of the real estate market for Australia, Japan or the UK at time $t$. $R_{U S, t}$ is the continuous return for of US real estate market. $D_{t}$ is an binary indicator variable that has a value equal to zero for the period before crisis and it has a value equal to one for each observation during the period after the crisis. The break period is $t \geq 2007: 08: 01$. The stochastic error term is denoted by $u_{t}$. This error term does not have to be necessarily normally distributed with constant variance because the method that we are applying does not require these assumptions. If the estimated value of the parameter $b_{2}$ is statically significant it means that the contagion effect prevails.

A new bootstrap approach that performs accurately when the data is non-normal with time varying volatility has been developed by Hatemi-J and Hacker (2005). This method is used to estimate and test the statistical significance of the parameters $a_{1}, a_{2}, b_{1}$ and $b_{2}$ in model (1). In order to describe the method compactly we express equation (1) in matrix format as

$$
Y=B X+u
$$

where

$$
\begin{aligned}
Y & =\left[\begin{array}{l}
R_{i, 1} \\
R_{i, 2} \\
\vdots \\
R_{i, T}
\end{array}\right] \text { a }(T \times 1) \text { vector, } X=\left[\begin{array}{cccc}
1 & R_{U S, 1} & D_{1} & D_{1} R_{U S, 1} \\
1 & R_{U S, 2} & D_{2} & D_{2} R_{U S, 2} \\
\vdots & \vdots & \vdots & \vdots \\
1 & R_{U S, T} & D_{T} & D_{T} R_{U S, T}
\end{array}\right] \text { a }(T \times 4) \text { matrix, } \\
B & =\left[\begin{array}{llll}
a_{1} & a_{2} & b_{1} & b_{2}
\end{array}\right] \text { a }(4 \times 1) \text { vector, and } u=\left[\begin{array}{l}
u_{1} \\
u_{2} \\
\vdots \\
u_{T}
\end{array}\right] \text { a }(T \times 1) \text { vector. }
\end{aligned}
$$

The ordinary least squares estimator for the parameter vector is provided by

$$
\hat{B}=\left(X^{\prime} X\right)^{-1} X^{\prime} Y \text {. }
$$

The pairwise bootstrap approach is implemented via the following steps:

1. First, create the variables $Y$ and $X$ by means of resampling with replacement (indicated as $Y^{*}$ and $X^{*}$ ), i.e. produce: 
$Y^{*}=\left\{Y_{1}^{*}, Y_{2}^{*}, \cdots, Y_{T}^{*}\right\}, \quad Y_{i}^{*} \in Y \forall i$. Where $i=1, \cdots, T$. where $T$ is the size of the bootstrap sample. Likewise

$$
X^{*}=\left\{X_{1}^{*}, X_{2}^{*}, \cdots, X_{T}^{*}\right\}, \quad X_{i}^{*} \in X \forall i \text {. Where } i=1, \cdots, T .
$$

2. Second, we estimate the parameters ( $\hat{B}$ ) using $Y^{*}$ and $X^{*}$. That is, we estimate

$$
\hat{B}=\left(X^{*} X^{*}\right)^{-1} X^{*} Y^{*} \text {. }
$$

3. Third, we repeat the two above steps 10000 times.

4. Finally, we acquire the casewise bootstrap coefficient vector $\left(\hat{B}^{*}\right)$ by taking the median. The median is used instead of the mean value because the mean value is sensitive to the extreme values.

We apply the bootstrap method to test the statistical significance of each element in $\hat{B}^{*}$. In particular, we perform the following procedures to obtain the casewise bootstrap p-value that corresponds to the hypothesis $H_{0}: r B=0$, where $r$ is a four by one vector that identifies the restrictions. For instance, if the null hypothesis $a_{1}=0$ is tested, then $r=\left[\begin{array}{llll}1 & 0 & 0 & 0\end{array}\right]$. As a first step in deriving the bootstrap p-value for $r B$, we rank the calculated values for $\hat{B}^{*}$. If the estimated value of the median for $r B^{*}$ is greater than zero, then the $\mathrm{p}$-value is equal to the proportion of elements in the bootstrap distribution for $r B^{*}$ that are negative plus those that are greater than twice the median. On the other hand, if the estimated median for $r B^{*}$ is less than zero, then the p-value is the proportion of elements in the bootstrap distribution for $r B^{*}$ that are positive plus the proportion of elements in $r B^{*}$ that are less than twice the median. P-values that are analogous to those associated with symmetric two-sided tests in traditional hypothesis testing are generated by the cut-off point of twice the median of $r B^{*}$, as explained in Hatemi-J and Hacker (2005).

\section{Data and Empirical Results}

In this paper we test for contagion effect from the US real estate market to Australia, Japan and the UK real estate markets. As stated earlier, it is not clear theoretically as well as from the literature as to the extent by which contagion effects can characterise the interaction in 
real estate markets. In this section, we present the empirical results derived from the application of the Hatemi-J and Hacker (2005) contagion test.

\subsection{Data}

For purposes of diversification, real estate serves as an important component of investors' portfolios due to its many attractive characteristics such as its stable and predictable increase in value over time, its strong performance yet low correlation vis-a-vis such traditional asset classes as stocks and bonds domestically and across countries, and , especially, for its ability to act as an inflation hedge which has been documented, for instance, by Hudson et al. (2003) among others (Yunus, 2009 and Bond et al. 2006). However, physical real estate has the drawback of being "lumpy" and "relatively illiquid”. The processing of transactions relating to investment in physical properties may drag on for six months to even one year (Bond and Hwang, 2004).

An alternative method for investing in real estate that overcomes these disadvantages of physical real estate is investing through real estate securities. As pointed out by Yunus (2009), since the advent of securitization in the early 1960s and especially over the last decade, REITs (real estate investment trusts), REOCs (real estate operating companies) and private indirect vehicles have emerged as viable alternatives to domestic commercial real estate ownership, making real estate available, albeit indirectly, to a wide audience. With institutional investors' increased demand for these securities, countries other than the US have also started to introduce tax-transparent REITs or REIT-like structures throughout the world, thereby fostering the growth and indirectly promoting the transparency of the global real estate securities market. This growth is evidenced by the fact that, according to NAREIT, the global market capitalization of publicly traded property securities has grown $170 \%$ from approximately $\$ 350$ billion to $\$ 945$ billion over the 7-year period beginning January 2000 and ending March $2007 .{ }^{4}$

\footnotetext{
4 In terms of absolute value, Wilson and Zurbruegg (2003) report that the US has the largest securitised property market (known as Real Estate Investment Trusts or REITs), although, proportionately, the US securitised sector is smaller than some of the securitised property markets of Asia or Europe. For instance, about 55\% of all institutional grade real estate recorded in the Australian Property Council's database is listed, compared with similar listings for the US of 18\%, the United Kingdom of $17 \%$ and Japan of $10 \%$, as pointed out by Steinert and Crowe (2001).
} 
In this paper, we therefore focus on the securitised (equities) segment of the real estate market. By doing so, we are able to use higher frequency data than what can be obtained from the direct real estate market. This is advantageous in the investigation of contagion since contagion is often transmitted between markets in short time horizons. The data employed in this study consist of publicly traded real estate stock price indices, quoted on a weekly basis, from Datastream for the four real estate markets under study, namely the United States, United Kingdom, Japan and Australia —over the period 2005 to 2009 which yielded a total of 255 observations. “Datastream’s Real Estate Index aims to represent securitized real estate markets. The Thomson Datastream database constitutes the universe from which the index is drawn. Companies included in the index represent around $75-80 \%$ of the total market capitalization. Suitability for inclusion in the index is determined by market value and availability of the data. There are no liquidity requirements as well as no adjustments for non-public holdings of shares or for cross-holdings. The index constituents are reviewed at a quarterly basis and re-set to represent the new top group of stocks by market value” (Serrano and Hoesli, 2009).

The period of the structural break is chosen to be at August 1, 2007 because this was when the real estate problem developed into a crisis (Kiff and Mills, 2008 and Dell'Ariccia, et al. 2008 and Frank and Hesse, 2009). We provide a brief account, in the subsequent paragraphs, as to how the crisis US real crisis eventuated in the summer of 2007. The beginnings of the crisis can actually be traced back to the middle of 2005 when home repayment delinquency rates actually started to pick up which then continued to increase in 2006 (Federal Reserve Bank of San Francisco 2008). By the middle of 2006, housing prices in the US began to decline and sub-prime mortgage foreclosures started to increase (OFHEO 2008a). Mortgage lenders with re-purchase provisions for their loans were called upon to undertake repurchases in the fourth quarter of 2006 (Krinsman 2007) but at the same time, investment banks started shutting down credit lines to independent mortgage lenders (Tavakoli 2008). This therefore resulted in a funding difficulty for those lenders who were undertaking repurchases of delinquent mortgages (Greenlaw et al. 2008).

It was not, however, until the summer of 2007 that this situation developed into a full-blown crisis. This was precipitated by deteriorating quality of U.S. subprime mortgages, a credit, rather than a liquidity event. Increased delinquencies on subprime mortgages, driven by rising interest rates for refinancing and falling house prices, resulted in uncertainty 
surrounding the value of a number of structured credit products which had these assets in their underlying portfolios. As a result, rating agencies downgraded many of the related securities and announced changes in their methodologies for rating such products. This rapidly propagated across different asset classes and financial markets. The rating agencies began issuing warnings about subprime real estate mortgage backed securities and collateralised debt obligations (CDOs) in the spring of 2007. By April, New Century Financial Corporation, the second-largest subprime lender in 2006, succumbed to borrower defaults - one of many such lenders to disappear. In June, two Bear Stearns hedge funds failed, brought down by their investments in subprime CDOs-especially toxic waste tranches; one of the funds was leveraged by more than 21-to-1 (Kelly and Ng 2007). In July, the credit-rating agencies downgraded hundreds of subprime tranches. The German bank IKB took a substantial hit on U.S. subprime mortgage investments and required an emergency infusion of funds from shareholders and the German government. In August, the French bank BNP Paribas was forced to halt redemptions from three funds that could not be valued because their subprime holdings had become so illiquid. During the summer of 2007, liquidity therefore evaporated in the credit markets for short-term papers with mortgages representing the single largest type of collateral and with holders of short-term papers not knowing how much of these backed up by sub-prime mortgages (Criado and Van Rixtel 2008). The US real estate and sub-prime crisis had indeed truly arrived in the summer of 2007.

\subsection{Diagnostic Test Results}

The continuous return of each variable is used. The data were tested for normality and ARCH effects. As can be seen from Table 1, the null hypotheses of normality and no ARCH effects were strongly rejected.

\section{[Insert Table 1 Here]}

The return for each market is reduced for the period after the crisis compared to the period before the crisis. Further, the volatility has increased for each market. The tests show that the data set is non-normal and ARCH effects prevail, especially for the entire sample. These diagnostic tests point to the fact that the standard methods based on the assumption of normality with constant volatility would not perform accurately. Thus, the application of the 
pairwise bootstrap approach is of paramount importance in this case in order to be able to draw valid empirical inference.

We have also tested for unit roots in order to avoid spurious results. The test results that are presented in Table 2 indicate that the null hypothesis of one unit root can be rejected for each individual returns as well as the series within a panel as a group.

[Insert Table 2 Here]

\subsection{Results of Contagion Test}

We apply therefore the Hatemi-J and Hacker (2005) contagion test to circumvent these statistical problems. The empirical results are presented in Table 3. Based on these results we can deduce that the relationship between the US real estate market and other three markets cannot be characterised by contagion but rather dependency that prevails regardless of which state (normal or distress) that the markets are in. This is based on the fact that the negative change in the slope is not statistically significant in any case. It should be mentioned that the intercept, which can be considered as a measure of risk premium for investing in the US real estate market is not statistically significant in any of the cases investigated. This seems to be true in the sub-periods before as well as after the crisis.

\section{[Insert Table 3 Here]}

Thus, in spite of the great publicity and the panic in financial markets and the economic crisis that ensued, our analysis based on a new contagion test developed by Hacker and Hatemi-J (2005), shows that the US real estate market crisis did not bring contagion effects on the real estate markets of other countries. Our results are in line with the recent study of Fry, et al. (2008).

\section{Conclusions}

In this paper, we apply a new contagion test to investigate whether there is any contagion effect between the US real estate market with those of Australia, Japan and the UK. This new contagion test is based on a case-resampling bootstrap approach that performs accurately 
during a crisis period in which the assumptions of normality and constant variance are not fulfilled. Inspite of the severity of the US real estate crisis, we find that the relationship of the US real estate market with the other markets is not characterized by contagion effects but by simply a dependency behavior that prevails whether the markets are under distress or not. Thus, even with the globalization of real estate markets, it appears that these are less susceptible to contagion effects arising from international shocks. This indicates that real estate markets' interaction is guided more by fundamentals rather than by non-fundamentals that create herding behavior. These results also imply that real estate markets are efficient in processing information from each other. Our finding also support the desirability of real estate as a component of investment portfolios since the absence of contagion effects can lead to more stable correlations. Given that the real estate industry is a major cornerstone of major economies, our finding also provides positive news for economic regulators and policymakers.

\section{References}

Bardhan, A. and Kroll, C. (2007) Globalisation and the Real Estate Industry: Issues, Implications and Opportunities, paper prepared for the Sloan Industry Studies Annual Conference, Cambridge.

Bardhan, A., Edelstein, R. and Tsang, D. (2007) Global Financial Integration and Real Estate Security Returns, Electronic copy available at: http://ssrn.com/abstract=905313.

Bond S.A. and Patel, K. (2003) The conditional distribution of real estate returns: are higher moments time varying, J Real Estate Finance Econ 26:319-339.

Bond, S.A., Dungey, M. and Fry, R. (2006) A Web of Shocks: Crises across Asian Real Estate Markets, Journal of Real Estate Financial Economics, 32, 253-274.

Bond SA and Hwang S (2004) Liquidity risk and real estate: a quantitative approach to assessing risk, paper presented to the 2004 European Real Estate Society annual meeting. Milan, June 2004

Boyer, B. H., Gibson, M. S., and Loretan, M. (1999) Pitfalls in tests for changes in correlations, Board of Governors of the Federal Reserve System (U.S.), International Finance Discussion Papers: 597.

Calvo, S. and Reinhart, C. M. (1996) Capital Flows to Latin America: Is there Evidence of Contagion Effects? In Guillermo A. Calvo, Morris Goldstein, and Eduard Hochreiter, eds.: Private Captial Flows to Emerging Markets After the Mexican Crisis (Institute for International Economics, Washington, DC).

Calvo, G. (1999) Contagion in Emerging Markets: When Wall Street is a Carrier, Working Paper, University of Maryland.

Criado, Sarai, and Adrian van Rixtel (2008) "Structured Finance and the Financial Turmoil of 2007-2008.” Documentos Occasionales No. 0808, Banco de Espana (August).

Dell'Ariccia, Igan G., D., and Laeven L. (2008) "Credit Booms and Lending Standards: Evidence from the Subprime Mortgage Market, (unpublished; Washington: International Monetary Fund).

Baur, Dirk G. and Fry, Renee, Multivariate Contagion and Interdependence (2008) Available at SSRN: http://ssrn.com/abstract $=877725$ 
Eichengreen, B. J., Rose, A. K., and Wyplosz, C. A. (1996) Contagious currency crises, Scandinavian Journal of Economics 98, 463-484.

Eicholtz, P., Gugler, N., and Kok, N. (2009) Transparency, Integration, and the Costs of International Real Estate Investment, Electronic copy available at: http://ssrn.com/abstract=1346409.

Eichholtz, P.M.A. and Kok, N. (2007) "The EU REIT and the Internal Market for Real Estate," A Research Report from European Landowners' Organization.

Federal Reserve Bank of San Francisco (2008) "The Subprime Mortgage Market: National and Twelfth District Developments,” Annual Report.

Forbes, K. J. (2004) The Asian flu and Russian virus: the international transmission of crises in firm-level data, Journal of International Economics, 63, 59-92.

Forbes, K. J. and Rigobon, R. (2002) No Contagion, Only Interdependence: Measuring Stock Market Comovements, Journal of Finance, LVII(5), 2223-2261.

Frank, N. and Hesse, H. (2009) Financial Spillovers to Emerging Markets During the Global Financial Crisis, Working Paper WP/09/104, International Monetary Fund.

Fry, R., Martin, V. and Tang, C. (2008) A New Class of Tests of Contagion with Applications to Real Estate Markets, CAMA Working Paper 1/2008, Centre for Applied Macroeconomic Analysis, Australian National University, Canberra.

Glick, R. and Rose, A.K. (1999) "Contagion and trade: why are currency crises regional?”, Journal of International Money and Finance, 18, 4, 537-60.

Granger, C. W. J., Huang, B. and Yang, C. (2000) A bivariate causality between stock prices and exchange rates: evidence from recent Asian flu, The Quarterly Review of Economics and Finance, 40, 337-354.

Greenlaw, David, Jan Hatzius, Anil K. Kashyap, and Hyun Song Shin. 2008. "Leveraged Losses: Lessons from the Mortgage Market Meltdown.” U.S. Monetary Policy Forum: 8-59.

Gromb, Dennis, and Dimitrios Vayanos, 2002, Equilibrium and Welfare in Markets with Financially Constrained Arbitageuers, Journal of Financial Economics, 66, 361-407.

Hamao, Y., Masulis, R. W., and Ng, V. K. (1990) Correlations in price changes and volatility across international stock markets, The Review of Financial Studies, 3, 281-307.

Hacker R.S. and Hatemi-J A. (2009) ContagT: GAUSS module to implement a pairwise bootstrap test for contagion, Boston College Department of Economics, Statistical Software Components, number G00007.

Hatemi-J, A. and Hacker, R. S. (2005) An Alternative Method to Test for Contagion with an Application to the Asian Financial Crisis, Applied Financial Economics Letters, 1(6), 343347.

Hatemi-J, A, and Roca, E. (2005) Exchange rates and stock prices interaction during good and bad times: evidence from the ASEAN4 countries, Applied Financial Economics, 15, 539-546.

Hobbs, P.; Chin, H. and Topintzi, E. (2007) "Global Real Estate Investment and Performance," London: RREEF Research

Hon, M.T., Strauss J. and Yong S.K. (2004) Contagion in Financial Markets after September 11: Myth or Reality?, Journal of Financial Research, 27, 95-114.

Hong, Harrison, and Jeremy C. Stein, (1999), Differences of Opinion, Rational Arbitrage and Market Crashes, Working paper, Stanford University and MIT.

Hudson-Wilson, S., Fabozzi F.J. and Gordon J.N. (2003) Why Real Estate? The Journal of Portfolio Management 29, 12-25.

JLL (2008) "From Opacity to Transparency.", J. L. LaSalle: London.

Jokipii, T. and Lucey, B. (2007), Contagion and Interdependence: Measuring CEE Banking Sector co-Movements, Economic Systems, 31, 71-96.

Kaminsky, G.L. and Schmukler, S.L. (1999), "What triggers market jitters? A chronicle of the Asian crisis”, Journal of International Money and Finance, 18, 537-60. 
Kelly, K. and Ng, S. (2007). "Bear Stearns Bails Out Fund with Big Loan.” Wall Street Journal (23 June).

Kiff, J., and Mills, P. (2008) "Money for Nothing and Checks for Free: Recent Developments in U.S. Subprime Mortgage Markets," IMF Working Paper 07/188 (Washington: International Monetary Fund).

King, M. A. and Wadhwani, S. (1990) Transmission of Volatility between Stock Markets, Review of Financial Studies, 3, 5-33.

Kodres, L. and Pritsker, M. (2002) A Rational Expectations Model of Contagion, Journal of Finance, 47, 2, 769-797.

Krinsman, Allan N. 2007. "Subprime Mortgage Meltdown: How Did It Happen and How Will It End?” Journal of Structured Finance, vol. 13, no. 2 (Summer):13-29.

Kyle, A. and Xiong, W. (2001) Contagion As A Wealth Effect, Journal of Finance, 56, 1401-1440.

La Porta, R.; Shleifer, A.; Lopez-De-Silanes, F. and Vishny, R.W. (2000) "Investor Protection and Corporate Governance." Journal of Financial Economics, 58, pp. 3-27.

Lee, S. B. and Kim, J. K. (1993) Does the October 1987 crash strengthen the comovements among national stock markets? Review of Financial Economics 3, 89-102.

Longin, F. M. and Solnik, B. (1995) Is the correlation in international equity returns constant: 1960-1990? Journal of International Money and Finance, 14, 3-26.

Loretan and English (2000) Evaluating "correlation breakdowns" during periods of market volatility, Board of Governors of the Federal Reserve System (U.S.), International Finance Discussion Papers: 658.

Masson, P. (1999) “Contagion: macroeconomic models with multiple equilibria”, Journal of International Money and Finance, 18, 4, 587-602.

Mun, S. (2005). Contagion and the Real Estate Markets of the Pacific Rim Countries, unpublished PhD Thesis submitted to the University of Auckland.

OFHEO. 2008a. "Mortgage Markets and the Enterprises in 2007," Office of Federal Housing Enterprise Oversight (July): www.ofheo.gov/media/research/MME2007.pdf.

Pretorius, A. and Beer, J. (2004) Contagion in Africa: South Africa and a Troubled Neighbour, Zimbabwe, Economic Modelling, 27, 95-114.

Romer, David (1993) Rational Asset-Price Movements without News, American Economic Review 83, 1112-1130.

Serrano, C. and Hoesli, M. (2009) Global Securitized Real Estate Benchmarks and Performance, Research Paper No. 08-39, Swiss Finance Institute.

Steinert, M. and Crowe, S. (2001) Global Real Estate Investment Characteristics, PortfolioAllocation and Future Trends, Pacific Rim Property Research Journal, 2001, 7(4), 223-239.

Tavakoli, Janet M. (2008) Structured Finance and Collateralized Debt Obligations: New Developments in Cash and Synthetic Securitization. Hoboken, NJ: John Wiley.

Xiong, Wei, 2001, Convergence Trading with Wealth Effects: An Amplification Mechanism in Financial Markets, Journal of Financial Economics 53, 247-292.

Wilson, P. and Zurbruegg, R. (2003) International Diversification of Real Estate Assets? Is It Worth It? Evidence from the Literature, Journal of Real Estate Literature, 11, 3, 259277.

Wilson, P. and Zurbruegg, R. (2004) Contagion or Interdependence? Evidence from Comovements in Asia Pacific Securitised Real Estate Markets During the 1997 Crisis, Journal of Property Investment \& Finance, 22, 5, 401-413.

Yuan, K. (2000) Asymmetric Price Movements and Borrowing Constraints: A Rational Expectations Equilibrium Model of Crisis, Contagion, Crisis and Confusion, $\mathrm{PhD}$ dissertation, Massachusetts Institute of Technology. 
Yunus, N. (2009) Increasing Convergence between U.S. and International Securitised Property Markets: Evidence Based on Cointegration Tests, Real Estate Economics, 37, 3, 383-411. 
Table 1: Descriptive statistics and diagnostic tests.

\begin{tabular}{|c|c|c|c|l|l|l|}
\hline \multirow{2}{*}{ Country } & Mean & SD & Max & Min & $\begin{array}{l}\text { P-value of } \\
\text { Normality } \\
\text { Test }\end{array}$ & $\begin{array}{l}\text { P-value of } \\
\text { ARCH test }\end{array}$ \\
\hline \multicolumn{7}{|c|}{ Entire Sample Period } \\
\hline US & -0.11109 & 2.3043 & 12.3395 & -11.0562 & 0.00001 & 0.00001 \\
\hline Japan & -0.0605 & 2.4195 & 5.83110 & -8.07671 & 0.00452 & 0.00001 \\
\hline UK & -0.1471 & 2.0654 & 7.44810 & -8.74501 & 0.00001 & 0.00001 \\
\hline Australia & -0.1577 & 1.8988 & 8.18784 & -9.08277 & 0.00001 & 0.00800 \\
\hline \multicolumn{7}{|c|}{ Before the Crisis } \\
\hline US & 0.08534 & 1.08320 & 2.5185 & -3.7819 & 0.00001 & 0.68050 \\
\hline Japan & 0.22751 & 1.71917 & 5.36459 & -5.1819 & 0.06032 & 0.00300 \\
\hline UK & 0.07290 & 2.06540 & 4.42530 & -3.7498 & 0.00019 & 0.00290 \\
\hline Australia & 0.06775 & 0.89626 & 2.57460 & -3.3271 & 0.02348 & 0.53330 \\
\hline Australia & -0.50981 & 2.76395 & 8.18784 & -9.08277 & 0.09946 & 0.58650 \\
\hline US & -0.40272 & 3.37551 & 12.33951 & -11.0562 & 0.000017 & 0.01730 \\
\hline Japan & -0.46877 & 3.15830 & 5.83110 & -8.07671 & 0.66077 & 0.01080 \\
\hline UK & -0.46877 & 2.88460 & 7.44810 & -8.74501 & 0.21713 & 0.0288 \\
\hline
\end{tabular}

Note: The Jarque-Bera test for normality is used. Engle's LM test is used to test for ARCH effects.

Table 2: Unit root test results.

\begin{tabular}{|c|c|}
\hline Variable & $\mathrm{H}_{0}: \mathrm{I}(1), \mathrm{H}_{1}: \mathrm{I}(0)$ \\
\hline US & 0.00001 \\
\hline Japan & 0.00001 \\
\hline UK & 0.00001 \\
\hline Australia & 0.04302 \\
\hline Panel & 0.00000 \\
\hline
\end{tabular}

Note: The Phillips-Perron test was used for testing the null hypothesis of one unit root in each individual series. Im, Peseran and Shin test was used to test for the panel unit root. The p-values are presented. 
Table 3. The results based on case-resampling bootstrap method.

\begin{tabular}{|c|c|c|c|c|}
\hline \hline Country & Intercept $\left(a_{1}\right)$ & Change in Intercept $\left(a_{2}\right)$ & Slope $\left(b_{1}\right)$ & Change in Slope $\left(b_{2}\right)$ \\
\hline \multirow{2}{*}{ Australia } & 0.0588 & -0.3528 & 0.3021 & -0.0329 \\
& $(0.4209)$ & $(0.1415)$ & $(0.0003)$ & $(0.8257)$ \\
\hline \multirow{2}{*}{ Japan } & 0.1686 & -0.4695 & 0.5651 & -0.2651 \\
& $(0.2304)$ & $(0.1035)$ & $(0.0001)$ & $(0.1446)$ \\
\hline \multirow{2}{*}{ UK } & 0.0397 & -0.2139 & 0.5833 & -0.0424 \\
& $(0.6737)$ & $(0.3229)$ & $(<0.0001)$ & $(0.7398)$ \\
\hline
\end{tabular}

Notes:

1. The parameters are estimated by case-resampling bootstrap method. Median values are presented.

2. The p-values based on the casewise bootstrap approach are presented in the parentheses. 